pupal stage. One did not attempt to pupate but sickened and died, the second formed a cell in late June and remained therein in an arched position for several days; it approached the form of a pupa, the larval skin softening considerably, and the imaginal eyes could be seen through this integument, but it perished without any ecdysis.

\title{
A NEW ANOPHELINE.
}

\section{By C. S. Ludlow,}

\section{Army Medical Museum, Washington, D. C.}

The Anopheline to be described is an unusually brilliantly marked one, the very marked spotting of the legs and wings being at once noticeable. It probably lies nearest ludlowii but the wing markings are quite different, the palpal bands are all narrow, and the legs are very much more spotted than even the most distinctly marked specimen of ludlowii which I have seen.

\section{Myzomyia parangensis sp. nov.}

9. Head brown covered with white and dark brown forked scales, the white ones on the vertex and spreading laterad about one-half the width of the eyes, the brown fork scales on the rest of the head except a long tuft of slender white scales projecting forward between the eyes; antennæ brown, verticels and pubescence white, a few white scales on the proximal joints, basal joint brown with "frosty tomentum"; palpi fairly heavily scaled, the scales outstanding, brown except a small white tip and narrow white bands at the base of the penultimate and at the base of the antipenultimate, the apical joint is very short; proboscis brown, labella light; clypeus brown; eyes brown.

Thorax; prothoracic lobes dark brown with long, yellow bristles; mesothorax a soft yellow, covered with "frosty tomentum" and sparsely by light yellow to white fine hair-like scales, more apparent in a median line of them, and long white scales projecting over the nape, but not confined to the very middle portion. A brown median line widening at the caudal margin, and continued still more broadly on the scutellum; scutellum much as mesonotum; pleura very dark brown with lines of white "frosty tomentum"; metanotum brown.

Abdomen dark brown covered with golden brown hairs, and a few long, light spatulate scales on the apex of the eighth segment; the genitalia are also covered with long spatulate scales.

Legs: coxæ and trochanters white; femora very markedly spotted or ringed in brown and white, there being no marked predominance of either color, the spots 
rather large, the very apices light, but sometimes only faintly so; tibiæ like femora, but the apices more distinctly white; the first tarsal joints are also markedly spotted and have an apical white band; the second tarsal joints are both apically and basally banded, more broadly in the fore legs, in the fore and mid legs usually with one intermediate spot, on the hind legs there are several intermediate spots; the third tarsals all have apical and basal light bands and at least one intermediate spot on the hind legs; the fourth tarsals have apical and basal bands, broader on the fore and mid legs, and the hind legs have the intermediate spot; the fifth tarsals are all basally light banded, and in some specimens at least a suggestion of an apical band. Ungues simple and equal. The bandings and spots on the hind tarsals, especially where there are only a few or one spot, divide the legs so they seem quite evenly marked brown and white.

Wings light yellowish much mottled with dark brown. The costa has six brown spots and a mere dot, the last practically at the junction of the first longitudinal vein with the costa; proximad is a small white spot followed by a larger dark one extending on to the first longitudinal and the upper fork of the second long vein, then comes a light spot about three times as long as this second dark spot followed by a small dark spot, about half as long as the preceding dark spot and extending on to the first long vein, then a long light spot followed by the third dark spot which is the largest of all the dark spots, the distal third extending on the sub-costa, the first long vein, on the stem of the second long vein and on the third long vein, the last two veins being less heavily marked than those celphalad of them, there is then on all these veins but the costa a light portion running under the remainder of the costal dark spot until the very proximal end where the dark again extends as a tiny spot on the sub-costa and first long vein. The fourth dark spot is not so long and extends on the sub-costa and first long vein; the fifth dark spot is small, and on the costa only, and the sixth spot is longer but also only on the costa. The wing field is much spotted. A small spot besides the "dot" spoken of on the upper fork of the second long vein near the base of the cell and two on the lower fork, the one near the apex small, and there is one on the stem near the junction of the sub-costa with the costa. The third long vein is mostly light, there being besides the dark spot connected with the large costal spot another dark spot just exterior to it and one near the apex of the vein; the fourth long vein has two spots on the stem and two on each fork; the fifth long vein is mostly light, but has one dark spot on the stem towards the base, and three on its upper fork; the sixth long vein has three dark spots, one near the base, one about the middle, and one near the apex. The fringe is much mottled and is light at the junction of all the veins except the upper fork of the second long vein and at the junction of the sixth, and has also light mid spots between the upper and lower forks of the fifth, between the fifth and the sixth and beyond the sixth it is light save for two dark spots just interior to this vein. The apices of all the veins are light. Halteres with dark knobs and light stems.

Length: about $7 \mathrm{~mm}$.

Habitat: Parang, Mindanao, Philippine Islands.

Taken: October and November. 

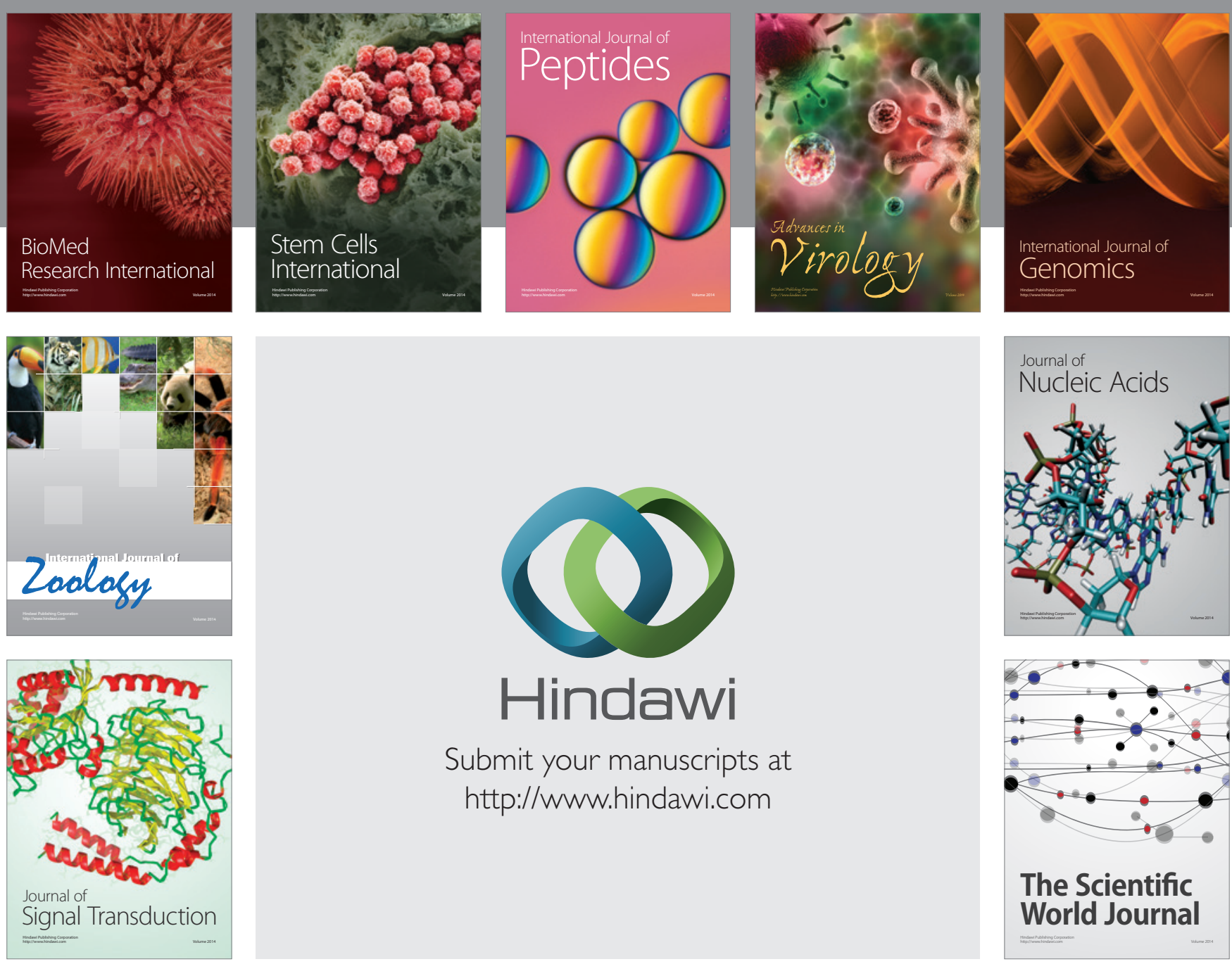

Submit your manuscripts at

http://www.hindawi.com
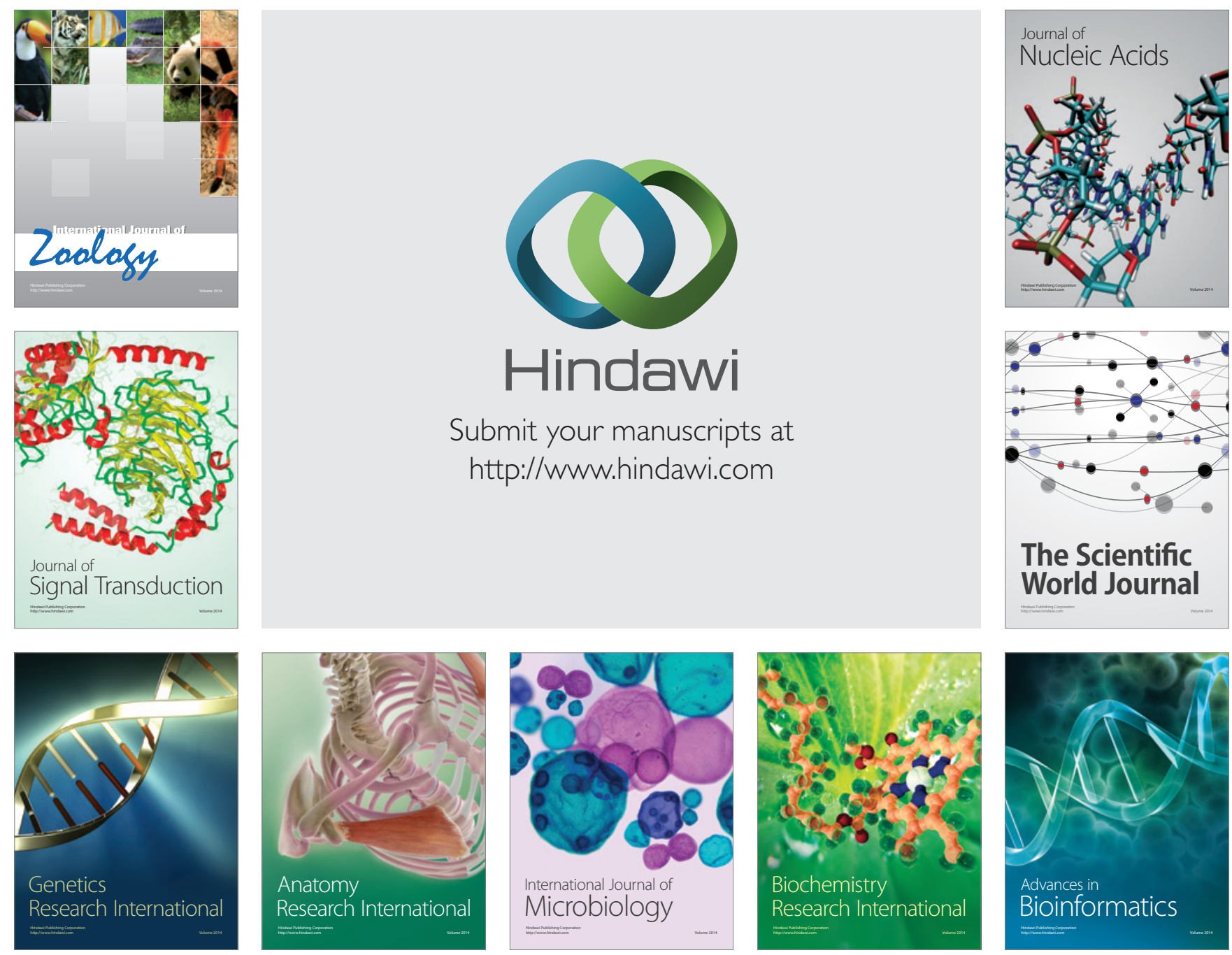

The Scientific World Journal
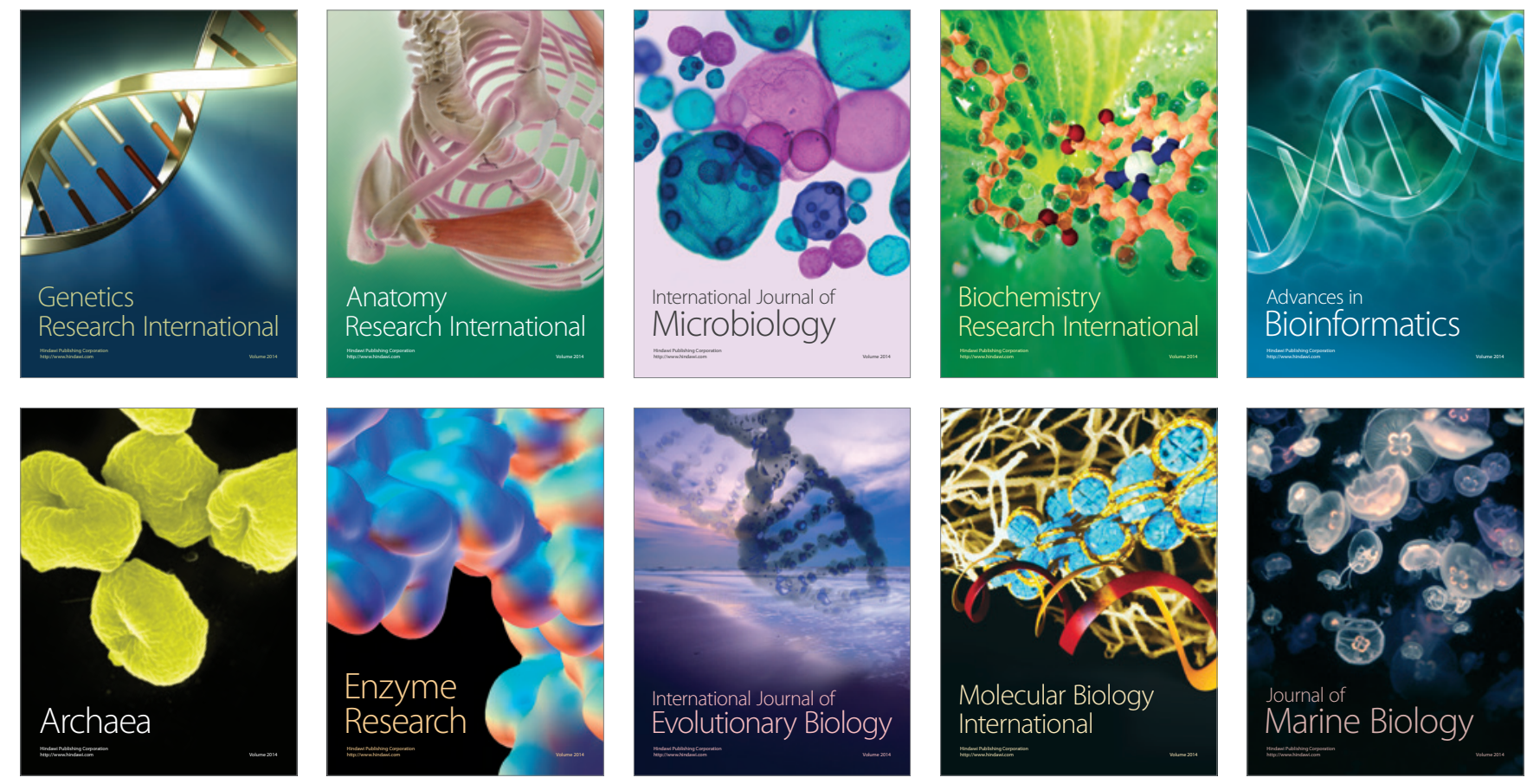